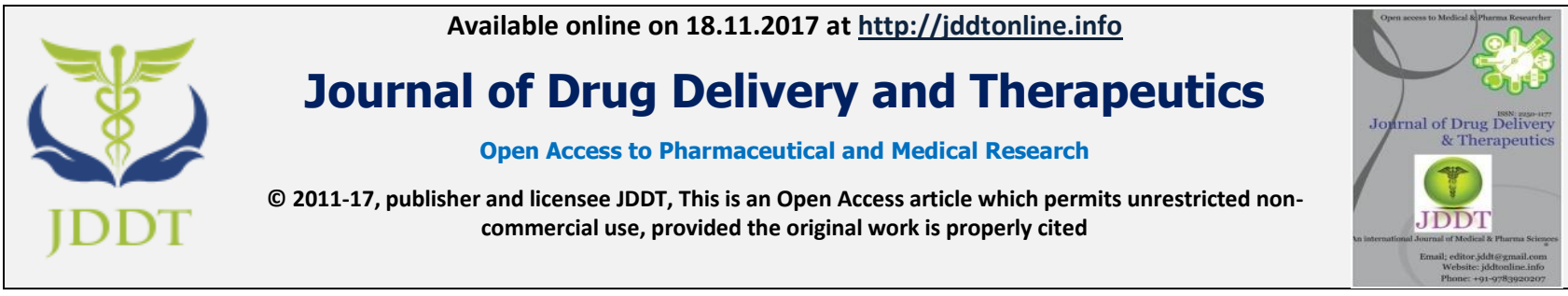

Open $\odot$ Access

Review Article

\title{
EXPLORING PHYTOCHEMICALS AND PHARMACOLOGICAL USES OF CORDIA DICHOTOMA (INDIAN CHERRY): A REVIEW
}

\author{
Sunil Kumar Prajapati ${ }^{1}$, Mousumi Kar ${ }^{2}$, Sheo Datta Maurya ${ }^{3}$, Richa Pandey ${ }^{3}$, Ram C Dhakar ${ }^{* 4}$ \\ ${ }^{1}$ Professor, Institute of Pharmacy, Bundelkhand University, Jhansi, India \\ ${ }^{2}$ Professor, College of Pharmacy, IPS Academy, Knowledge Village, Rajendra Nagar, AB Road, Indore-452012, (M.P.), India \\ ${ }^{3}$ Associate Professor, Department of Pharmacy, IEC Group of Institution, Greater Noida, India-201306 \\ ${ }^{4}$ Dept of Medicine (OPD), Jhalawar Medical College and Hospital, N.H.-12, Jhalawar, Rajasthan, India-326001
}

\begin{abstract}
The use of phytoconstituents single or combined with standard medicines has been utilized in cure of different diseases. Many plants of genus Cordia comprise of trees and shrubs are widely distributed in warmer regions and have been utilized in management of various diseases. Various phytoconstituents like flavonoids, alkaloids, terpenes, tannins, and glyceridess having different activities were screened and isolated from different parts of $C$. dichotoma. Various important Pharmacological properties including Antiulcer, Contraceptives, anti-inflammatory, anthelmintic, analgesic, anticancer, Antioxidant, antimicrobial, hepatoprotective, antidiabetic and others have been well documented for this plant. Therefore, we have briefly reviewed the various bioactivities of $C$. dichotoma to improve our knowledge on plant phytochemicals as therapeutic entities. The present review describes the various phytoconstituents and therapeutic potential of $C$. dichotoma that can be followed for future research on this plant for human health benefits.
\end{abstract}

Keywords: Cordia Dichotoma, phytoconstituents, Antioxidant, Antimicrobial, Antifertility, Traditional medicine

Article Info: Received 26 March, 2017; Review Completed 23 April, 2017; Accepted 28 Nov, 2017; Available online 28 Nov, 2017

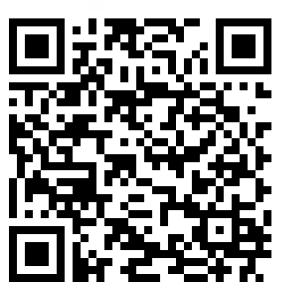

Cite this article as:

Prajapati SK, Kar M, Maurya SD, Pandey R, Dhakar RC, Exploring Phytochemicals and Pharmacological Uses of Cordia dichotoma (Indian cherry): A review, Journal of Drug Delivery and Therapeutics. 2017; 7(6):125-131 DOI: http://dx.doi.org/10.22270/jddt.v7i6.1438

*Address for Correspondence

Ram C Dhakar, Jhalawar Medical College and Hospital, N.H.-12, Jhalawar, Rajasthan, India-326001, E-mail: dhakar_rc@yahoo.co.in

\section{INTRODUCTION}

Since ancient times, various natural medicines in different dosage forms have been attempted for the management of various diseases. Management of diseases with these agents free of any adverse effects is now also a big challenge for the researchers. There is increasing interest in natural medicine owing to these reasons. In popular medicine, the plant species of the genus Cordia have been tried for the treatment of various illnesses that affect many human systems. $C$. dichotoma is a plant of subtropical and tropical regions. Many phytoconstituents like flavonoids, terpenes, alkaloids, tannins and glycerides having different pharmacological action were screened and isolated from C. dichotoma. Many researchers reported various pharmacological applications of $C$. dichotoma such as Anti-ulcer ${ }^{1}$, Contraceptives ${ }^{2}$, anti-inflammatory ${ }^{3-6}$ anthelmintic, analgesic, anticancer ${ }^{4,7}$, Antioxdant ${ }^{8,9}$, antimicrobial $^{10}$, antifungal ${ }^{10}$, hepatoprotective ${ }^{11}$ and diuretic purposes and for treating digestive system, respiratory, urogenital, cardiac, vascular and blood disorders. So far only few numbers of comprehensive reviews has been compiled from the literature encompassing the therapeutics uses of cordial dichotoma. Thus objectives of the present review are to provide an overview of the recent status on phytoconstituents and pharmacological uses of plants $C$. dichotoma. 


\section{Classification:}

It is classified as Kingdom: Plantae; Division: Magnoliophyta; Class: Dicotyledons; Subclass: Astaridae; Order: Lamiales; Family: Boraginaceae; Genus: Cordia; Species: C. dichotoma Forst.

\section{Vernacular Names:}

Sanskrit: Bahuvaraka, Bhukampadaruka, Bhukarbudara, Bhuselu, Bhutadruma, Laghupichhila; Hindi/Indian: Bhairala, Bhokar, Gondi, Guslasah, Lasora; English: Sebesten Plum, Fragrant manjack, soap berry; Lepcha: Ninut; Sinhalese: Lolu, Lotu; Unani: Sapistan; Arabic: Dabk; Myanmar: Thanet; Java: Kendal; Persian: Sugpistan, Sebestan, Sapistan; Tehran: Sepistan; SinoTibetan: Lao; Malay: petekat; Nepali: kalo bohori, bohori; Thai: Mandong, manma; Philippines: Anonang; Sumatran: Nunang.

\section{Local Names:}

Assam: Dilk; Bengali: Bohari, buhul; Gujarati: Vadagunda; Marathi: Bhokar, Bhonkar; Kannada: Chikkachalli; Malayalam: Naruvari; Punjabi: Lasuda; Telugu: Nakkera; Tamil: Naruvili, Selu, Vidi
C. dichotoma is a tree that found in tropical and subtropical regions. It grows in the sub-Himalayan tract and outer ranges, ascending up to about $1500 \mathrm{~m}$ elevation. It is found in different types of forests ranging from the moist deciduous forests of the Western Ghats and tidal forests in Mayanmar to the dry deciduous forest of Rajasthan. In Maharashtra, it grows in the moist monsoon forest also ${ }^{4}$.

\section{Botanical description:}

C. dichotoma family Boraginaceae is a small to moderate size deciduous tree with a short bole, short crooked trunk and spreading crown. The stem bark is grayish brown in color, longitudinally wrinkled or smooth. Leaves are simple, entire and slightly dentate, elliptical-lanceolate to broad ovate with the round and cordate base. These flowers are $25 \mathrm{~mm}$ long, dull pinkish edible fruits with sticky flesh flowers are shortstalked, bisexual and white in color, appear in loose corymbose cymes. ${ }^{12}$ The fruit is a yellow or greenishyellow shining globose or ovoid drupe seated in a saucer-like enlarged calyx (figure 1). It turns black on ripening and the pulp gets viscid. The hard stone is 1-4 seeded.

Distribution:

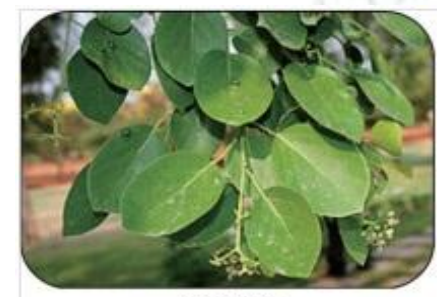

Leaves

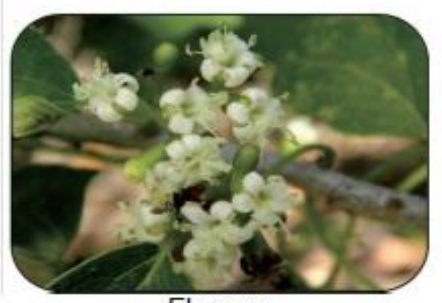

Flowers

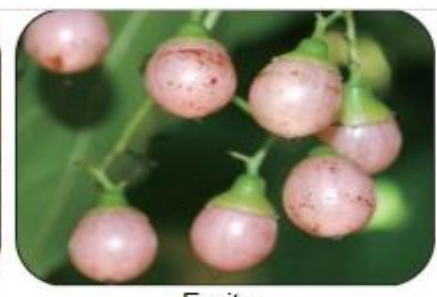

Fruits

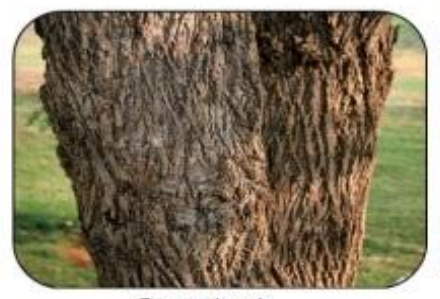

Stem bark

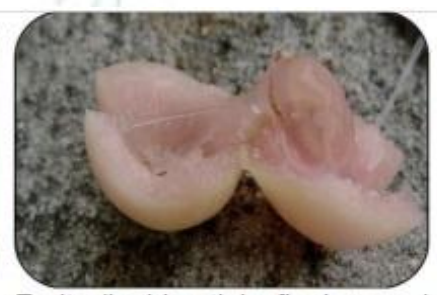

Fruits (inside sticky flesh mass)

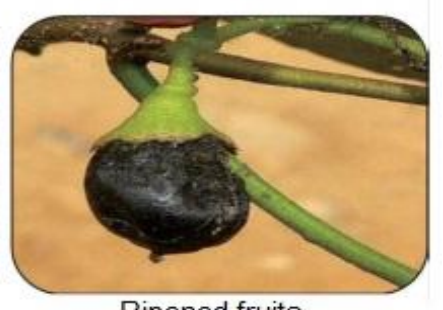

Ripened fruits

Figure 1: Various Parts of Cordia dichotoma plant $^{3}$

\section{PHYTOCHEMISTRY}

The plants of the genus Cordia serve as a rich source of phytoconstituents. Various researchers have carried out phytochemical studies resulting in the identification and isolation of various phytoconstituents and different classes of secondary metabolites from different parts of C. dichotoma.

Several bioactive compounds were identified in the seeds of $C$. dichotoma [figure 2]. The seed contains $\alpha-$ amyrins $^{3,4}$, betulin ${ }^{6}$, octacosanol, lupeol-3-rhamnoside, $\beta$-sitosterol ${ }^{4}, \beta$-sitosterol-3-glucoside, hentricontanol, hentriacontane, taxifolin-3-5-dirhamnoside ${ }^{6}$, hesperitin7-rhamnoside and fatty acids such as palmitic acid, stearic acid, arachidic acid, behenic acid, oleic acid and linoleic acid. Flavonoid glycosides (rutoside, robinin, rutin, datiscoside and hesperidin), flavonoid aglycone (dihydrorobinetin) and phenolic derivatives (chlorogenic acid and caffeic acid) were also isolated from seeds ${ }^{4}$. The significant anti-inflammatory activity of seeds may be attributed because of $\alpha$-amyrins and taxifolin-3-5dirhamnoside ${ }^{3,6}$.

Leaves have been identified for pyrrolizidine alkaloids, coumarins, flavonoids, saponins, terpenes, sterols ${ }^{4}$ (e.g. 4-hydroxy-transcinnamate ester ${ }^{8}, 13$, $\beta$-sitosterol ${ }^{4,14}$, quercetin and quercitrin $\left.{ }^{11,15}\right)$. Preliminary phytochemical analysis of $\mathrm{C}$. dichotoma bark indicated the presence of allantoin, $\beta$-sitosterol and 3', 5-dihydroxy-4'- methoxy flavanone-7-O-alpha-L-rhamnopyranoside ${ }^{4,16}$. Fruits showed the presence of pyrrolizidine alkaloids, coumarins, flavonoids, saponins, terpenes, sterols ${ }^{4}$, arabinoglucan, D-glucose $(67.6 \%)$ and L-arabinose $(13.2 \%)^{11,7}$. Phytoconstituents with their possible pharmacological actions are listed in table 1 and structures of some phytoconstituents are presented in figure 2 . 
<smiles>COc1ccc([C@@H]2CC(=O)c3c(O)cc(OC4OC(CO[C@H]5O[C@@H](C)C(O)[C@@H](O)[C@H]5O)[C@@H](O)C(O)[C@H]4O)cc3O2)cc1O</smiles>

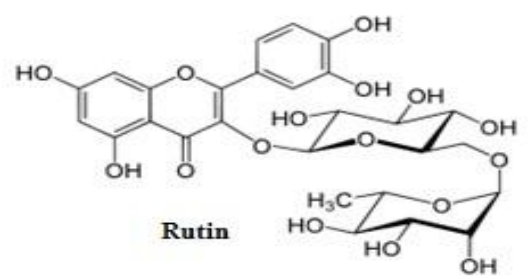

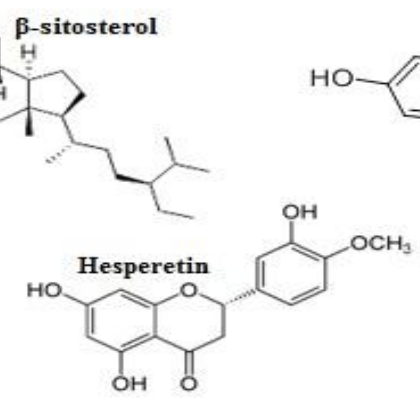<smiles>O=c1cc(-c2ccccc2)oc2cc(O)cc(O)c12</smiles>

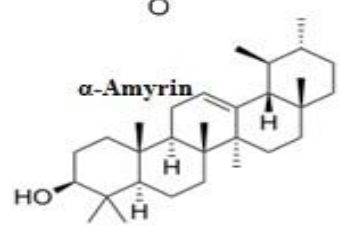<smiles>O=C(O)C(=O)Oc1cc(O)ccc1-c1oc2cc(O)cc(O)c2c(=O)c1O</smiles>

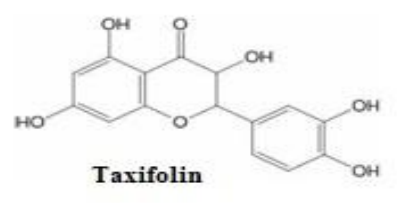

Figure 2: List of identified phytoconstituents of Cordia reported in the literature 1, 2, 3, 4, 5, 6, 7, 11

Table 1: List of identified phytoconstituents with pharmacological activity of C. dichotoma

\begin{tabular}{|c|c|c|c|}
\hline Parts used & Phytoconstituents & Pharmacological Activity & Ref \\
\hline Leaves & Apigenin & Ulcerative colitis & \\
\hline Leaves & Apigenin, Luteolin & Antifertility activity & 2 \\
\hline Seeds, Leaves & $\alpha$-Amyrin & Antiinflammatory & 3,4 \\
\hline Seeds & $\begin{array}{l}\text { Hentricontanol, Hesperetin, taxifolin- } \\
\text { 3-5-dirhamnoside }\end{array}$ & Antiinflammatory activity & 5 \\
\hline seeds & $\begin{array}{l}\text { betulin, octacosanol, flavonoids. } \\
\text { taxifolin } 3,5 \text {, dirhamnoside }\end{array}$ & Anti-inflammatory activity & 6 \\
\hline seeds & $\beta$-sitosterol & $\begin{array}{l}\text { Growth inhibitory effects on human breast MCF-7 } \\
\text { and MDA-MB- } 231 \text { adenocarcinoma cells }\end{array}$ & 4,7 \\
\hline Leaves & 4-hydroxy-transcinnamate Ester & DPPH radical scavenging activity & 8,13 \\
\hline Leaves & $\begin{array}{l}\alpha \text {-Sitosteryl-3 } \alpha \text {-glucopyranoside-6'- } \\
O \text {-palmitate }\end{array}$ & $\begin{array}{l}\text { cytotoxicity against Bowes (melanoma) and MCF7 } \\
\text { (breast) cancer cell lines }\end{array}$ & 8,14 \\
\hline leaves & Quercetin & Antioxdant activity and Antiinflammatory & 15 \\
\hline
\end{tabular}

\section{PHARMACOLOGICAL USES}

The pharmacological properties of $C$. dichotoma have been described since ancient times. It possesses antimicrobial ${ }^{10}$, antioxidant, analgesic, antiinflammatory ${ }^{5,6}$, hepatoprotective, aphrodisiac, diuretic, expectorant, laxative, antifertility ${ }^{2}$, anticancer ${ }^{4,8,14}$ and anthelmintic activity ${ }^{18}$.

Antimicrobial activity:

Several phytoconstituents from $C$. dichotoma are experimentally proved and used as antimicrobial agent against different microorganisms. Antibacterial activity of $C$. dichotoma may be attributed due to the presence of flavonoids/essential oils.

Extracts from the bark of $C$. dichotoma were tested against different bacteria (E. coli, Pseudomonas aeruginosa, S. pyogenes and S. aureus) and fungi (Aspergillus niger, Aspergillus clavatus and Candida albicans). It was found that the plant extract showed significant antimicrobial activities against all microorganisms and Zone of inhibition of extracts was compared with that of different standards like ampicillin, ciprofloxacin, norfloxacin and chloramphenicol. ${ }^{10}$.
Extracts from the fruits of $C$. dichotoma were tested for antibacterial activity against S. aureus, C. albicans and A. fumigates. S. aureus exhibited good susceptibility to acetone extract of $C$. dichotoma whereas $\mathrm{C}$. albicans and A. fumigatus were found resistant to $C$. dichotoma extracts. ${ }^{19}$

Kumari et al have synthesized the silver nanoparticles (AgNPs) using C. dichotoma leaf extract. AgNPs were studied for their potential role in antibacterial activity and photocatalytic degradation of azo dyes such as methylene blue and Congo red. The results showed that AgNPs exhibited potent antibacterial activity and high catalytic activity under the sunlight. These were capable of degrading the dyes such as methylene blue and Congo red ${ }^{20}$.

\section{Antioxidant activity:}

Free radicals are responsible for many diseases like arthritis, cancer, diabetes mellitus, aging, etc. Herbal antioxidants have gained great importance in recent years as they are utilizing in the management of such diseases due to their ability to neutralize free radicals. As plants are the source of natural antioxidants, much attention has been gain to plants. Currently, there has been an increased interest globally to identify anti- 
oxidant compound that has potent bioactivities and has low or no side effects. ${ }^{21}$

Antioxidant activity of plants may be attributed to presence of phenols, flavones, isoflavones, flavonoids, xanthones, alkaloids, anthraquinones, phytosterols, steroids, amino acids, anthocyanins, isothiocyanate indoles, coumarins lignans, catechins, and isocatechins $\operatorname{etc}^{22,23,24}$.

Many in vitro and in vivo studies on antioxidant activity of $C$. dichotoma are available in literature 5, 6, 9, 12, 22, 25, 26 Quercetin from $C$. dichotoma is a phytochemical with high antioxidant activity that has been shown to maintain blood pressure levels and thus improve cardiovascular function. Quercetin can inhibit platelet aggregation, increase nitric oxide activity and improve endothelial function. ${ }^{22,25}$

Free radicals are responsible for the immunomodulatory response, recruit inflammatory cells and are innately bactericidal. In the body, excess production of free radicals affects lipid cell membranes to produce lipid peroxides and reactive oxygen species (ROS), which result in decreasing membrane fluidity and many biological changes, such as aging, heart disease, DNA damage and cancer etc. Antioxidants act as free radical scavengers, neutralizing and defending the body from a number of diseases those are because of generation of free radicals. They offer defense against radical toxicity by antagonizing the damages caused by free radicals.

Sharma et al studied the role of free radical scavenging activity of $C$. dichotoma seeds and leaves extract in degenerative disorders ${ }^{12}$. These models demonstrate positive antioxidant activity in a concentration dependant manner and demonstrate that highest concentration exhibits highest $(100 \mu \mathrm{g} / \mathrm{ml})$ antioxidant activity. This activity was more pronounced in leaves as compared to seeds.

Singh et al. were tested methanolic extract of seeds and leaves of $C$. dichotoma for free radical scavenging potential in the management of degenerative disorders such as aging and age-associated oxidative stress related disorders. Activity was evaluated by in-vitro models (hydrogen peroxide and DPPH model). Both models showed positive antioxidant activity in a concentrationdependent manner and highest concentration exhibits highest $(100 \mu \mathrm{g} / \mathrm{mL})$ antioxidant activity. This activity was more pronounce in methanolic extract of leaves as compared to seeds ${ }^{6}$.

Nariya et al evaluated the phenolic contents and antioxidant potential of methanolic and butanol extract of $C$. dichotoma bark. In the present study three in vitro models were used to evaluate antioxidant activity. The first two methods employed direct measurement of radical scavenging activity and in remaining one method evaluated the reducing power. $C$. dichotoma showed strong antioxidant activity by inhibiting DPPH activity and reducing power activities when compared with standard 1-ascorbic acid. In addition, both the extracts were found to contain a noticeable amount of total phenols, which play a key role in controlling oxidation. The results present study show that the extract can be used as an easily available source of herbal antioxidant. The chemicals present in the bark such as alkaloids, terpenoids, reducing sugars, flavonoids, proteins, steroids, and tannins may be responsible for such activity ${ }^{9}$.

Shuge et al carried out a study aiming to determine the phytochemical composition and antioxidant activity of air-dried C. dichotoma seeds. The results from this study indicate that $C$. dichotoma seeds are a rich source of polyphenolic compounds and amino acids, which can be used for quality assessment. Results revealed that ethanolic extract of $C$. dichotoma seeds has good antioxidant capacity ${ }^{25}$.

Mahasweta et al has examined the antioxidant potential of $C$. dichotoma seeds. Hentricontanol Fraction, Hesperetin fraction and Taxifolin fraction from the seeds of $C$. dichotoma showed promising DPPH free radical scavenging activity at a concentration of 100 $\mu \mathrm{g} / \mathrm{mL}^{5}$.

\section{Antiulcer activity:}

The antiulcer effect of the extract of $C$. dichotoma fruit was studied in albino Wistar rat using three different models i.e. pyloric ligation, aspirin and indomethacininduced ulcers. The extractions of $C$. dichotoma fruits were carried out using ethanol. The extract was fractionated using petroleum ether, solvent ether, ethyl acetate, butanol and butanone in succession. In rats, injury in gastric mucosa was produced by pyloric ligation, aspirin and indomethacin-induced models. Fruits extracts of different solvents (petroleum ether, solvent ether, ethyl acetate, butanol and butanone) were administered in a dose of $300 \mathrm{mg} / \mathrm{kg}$ body weight. The results indicates that extracts of ethyl acetate, butane and butanone significantly $(\mathrm{p}<0.001)$ decrease the gastric secretion volume, free acidity, total acidity and ulcer index with respect to control. results of this study suggest that the extracts of $C$. dichotoma fruits possess significant antiulcer activity ${ }^{27}$.

Ganjare et el reported that apigenin $(5 \mathrm{mg} / \mathrm{kg}$, p.o.) from C. dichotoma showed significant ulcer healing and reduction in inflammatory enzymes when screened for ulcerative colitis ${ }^{1}$.

\section{Hepatoprotective Activity}

There are small numbers of drugs available for the treatment of liver disorders. Therefore, many folk remedies from plant origin are tested for its potential antioxidant and hepatoprotective liver damage in experimental animal model ${ }^{28,29}$.

The methanolic extract of the leaves of $\mathrm{C}$. dichotoma with of dose $300 \mathrm{mg} / \mathrm{kg}$ and $500 \mathrm{mg} / \mathrm{kg}$ were tested for hepatoprotective action in male Wistar rats. Liver damage is induced by carbon tetrachloride (CCl4) and Silymarin was used as standard drug for this study. The extract $(300 \mathrm{mg} / \mathrm{kg}$ ) significantly reduced the AST level $(\mathrm{P}<0.001)$, ALT level $(\mathrm{P}<0.001)$ and TBR levels $(\mathrm{P}<0.01)$ and at $500 \mathrm{mg} / \mathrm{kg}$ dose significantly reduced the ALT $(\mathrm{P}<0.001)$, TBR level $(\mathrm{P}<0.01)$, AST level $(\mathrm{P}<0.001)$ and lipid peroxide levels $(\mathrm{P}<0.05)$. The results showed that hepatoprotective activity of $\mathrm{C}$. 
dichotoma was found comparable with silymarin $(100 \mathrm{mg} / \mathrm{kg})^{29}$.

\section{Antifertility activity}

Traditionally, herbs are used as a first choice in the area of fertility control as they contains numerous phytoconstituents including steroidal components, flavonoids, terpenoids, alkaloids and steroidal saponins that are probably responsible for antifertility activity $5,30,31$.

Moreover, these phytoconstituents might cause certain toxic effects in the development or normal functioning of the reproductive system. Coumarin, flavonoid and sitosterol $^{8,14}$ are phytoconstituents that have been related to the occurrence of certain adverse effects to the reproductive system and hence possess a potent antifertility activity. Flavonoids like quercitin, apigenin $^{2,5}$, luteolin ${ }^{2,5}$ and $\beta$-sitosterol ${ }^{8,14}$ are the active constituents of this plant that suggests the possible antifertility activity in female rats.

Considering the safety/risk ratio of steroidal contraceptives, Bhattacharya et al evaluated the ethnocontraceptive action of leaves of $C$. dichotoma (LCD) on post-coital female albino rats. The leaves extract (LD50 $5.50 \mathrm{~g} / \mathrm{kg} \mathrm{BW}$ ) showed $100 \%$ antiimplantation activity $(\mathrm{n}=10)$ at $800 \mathrm{mg} / \mathrm{kg}$ dose level. (2hydroxypropyl)- $\beta$-cyclodextrin (BCD) was used as bioavailability enhancer to form LCD-BCD complex. The LCD-BCD complex (1:1, w/w) exhibited $100 \%$ pregnancy interception $(n=20)$ at the dose level of 250 $\mathrm{mg} / \mathrm{kg}$ and also showed strong estrogenic potential with a luteal phase defect. The LCD extract was standardized by a validated HPTLC method and two contraceptive phytoconstituents, apigenin and luteolin were isolated. The histological and biochemical estimations detected the reversible contraceptive potential after withdrawal. The developed formulation of standardized $C$. dichotoma leaf extract showed potent contraceptive potential. It has strong estrogenic potential but absent of major cardiovascular risks associated with estrogens, even after chronic administration 5 .

Sharma et al studied the antifertility activity of hydroalcoholic extract of $C$. dichotoma leaves at two dose level (200 and $400 \mathrm{mg} / \mathrm{kg}$, orally) in two experimental animal models i.e. antiimplantation and estrogenic/ antiestrogenic activity in female albino rats. A good antiimplantation (81.22\%) activity in female rats was observed at the tested dose levels (200 and 400 $\mathrm{mg} / \mathrm{kg}$, orally). The leaves extract further showed more significant $(\mathrm{P}<0.01)$ increase in weight of the uterus and significant change in biochemical parameters in immature rats. Simultaneous administration of extract along with ethinylestradiol showed significant estrogenic activity. The results suggest that hydroalcoholic extract of $C$. dichotoma leaves possess significant anti-fertility activity, which might be due to the presence of some estrogenic chemicals in leaves that cause inhibition of implantation. The steroidal glycosides, saponins are responsible for antiestrogenic activity of the extract as these are previously reported to reduce the activity of estrogens induced enzymes in several estrogen targeted tissues ${ }^{32}$.
Antiimplantation activity of methanolic extract of $C$. dichotoma Bark (BCD) was evaluated by Katolkar et al. BCD showed significant anti-implantation activity. Pretreatment with BCD showed significant inhibition of numbers of implant site at a dose of $100 \mathrm{mg} / \mathrm{kg}$ body weight. There was no change in ovulation; hence the anti-implantation activity observed in the present study with BCD can be attributed largely to its inhibition of numbers of implants. However, an investigation of the anti-implantation activity showed no increase in body weight or uterine content of blood glucose, cholesterol and triglyceride levels when compared with control group. The presence of chemical constituents in BCD like saponins, glycosides and flavonoids might be responsible for its anti-implantation activity. The present experimental findings suggest that BCD has antiimplantation activity, hence its anti-implantation action responsible for its antifertility activity ${ }^{33}$.

\section{Analgesic, anti-inflammatory and antipyretic activity:}

The anti-inflammatory activity of this plant is attributed to the presence and abundance of phytochemicals such as $\alpha$ - amyrins, betulin, octacosanol, fatty acid and flavonoids. $\alpha$-Amyrin and toxifolin 3,5 , dirhamnoside $e^{4,5,6,15}$.

Shahapurkar et al have prepared transdermal films using natural polymer from fruit gum of $C$. dichotoma. The films were tested for anti-inflammatory activity using carrgeenan induced raw paw odema model. The results were compared with standard drug, diclofenac sodium. The percentage of inhibition odema was considered as a mark of anti-inflammatory potential and it was found to be highest in $0.20 \%(\mathrm{w} / \mathrm{v})$ glycerin treated animal which indicates significant antiinflammatory activity of C. dichotoma ${ }^{34}$.

The C. dichotoma seeds showed good anti-inflammatory activity in Wistar rats as assayed by Sharma et al. At a dose of $500 \mathrm{mg} / \mathrm{kg}$, the aqueous and ethanolic extracts showed maximal inhibition of edema $(69.52 \%$ and $58.09 \%$, respectively) in relation to the control group, reveals the efficacy of the extract of $C$. dichotoma as an anti-inflammatory agent, which explains the wide use of this plant as an anti-edema agent in popular medicine ${ }^{35}$.

Gupta et al evaluated the analgesic, anti-inflammatory, and antipyretic activity of methanolic extract $C$. dichotoma leaves extract on the SD female rats. Methanol extract high dose $(400 \mathrm{mg} / \mathrm{kg})$ was found to be highly significant as compared to standard drug ${ }^{36}$. Therefore, results from various published work confirm and supports the traditional use of $C$. dichotoma for management of pyrexia, inflammation and painful conditions.

\section{Wound Healing activity:}

The need of herbal drugs is increasing day by day because they are safer and well tolerated in comparison to allopathic drugs. Numerous plants have been screened for their traditional use in the management of the wounds. In past two decades, different pharmacological activity of $C$. dichotoma has been 
reported by various research groups. But wound healing activity of this plant tested only by few researchers.

Fruits contain sufficient amount of flavonoids, saponins and amino acids those are might be responsible for wound healing activity of $C$. dichotoma. Study of fruit extracts of $C$ dichotoma showed significant wound healing activity in three different models, viz. excision, incision and dead space wound models in albino rats ${ }^{37}$. The extraction of fruits of $C$. dichotoma. was carried out using ethanol. Fruit extract was further fractionated using petroleum ether (40-60\%), solvent ether, ethyl acetate, butanol and butanone in succession. These fractions were tested for wound healing activity using three different models, viz. incision, excision and dead space wound models on either sex of albino rats of Wister strain. All the fractions showed significant $(\mathrm{P}<0.001)$ activity may be due to the presence of flavonoids in fruits.

\section{Antidiabetic activity:}

From ancient time plant species are used in the treatment of various diseases ${ }^{38}$. Management of diabetes with agents with no side effects is still a challenge to the medical system. There is growing interests in herbal remedies due to these reasons $39,40,41$

The effect of the aqueous extract of cordia dichotoma on alloxan induced and normoglycemic Wistar rats have been investigated. Three doses of the extract $(250 \mathrm{mg} / \mathrm{kg}$; $500 \mathrm{mg} / \mathrm{kg}$ and $1000 \mathrm{mg} / \mathrm{kg}$ ) were administered orally. The $500 \mathrm{mg} / \mathrm{kg}$ extract of $C$. dichotoma did not show any significant change in the blood sugar levels in normoglycemic and $250 \mathrm{mg} / \mathrm{kg}$ did not show any significant change in the blood sugar levels in alloxaninduced Diabetic Wistar rats when compared to untreated control. The dose $500 \& 1000 \mathrm{mg} / \mathrm{kg}$ of extract showed a significant $(\mathrm{p}<0.5)$ decrease in blood sugar levels after 4,8 , and 24 hours. In normoglycemic rats, the dose of $1000 \mathrm{mg} / \mathrm{kg}$ of the extract significantly $(\mathrm{p}<0.05)$ decrease the blood sugar levels at 8 and 24 hours. In conclusion, the doses of extract have shown both significant $(\mathrm{p}<0.05)$ hypoglycemic and antihyperglycemic effects in Wistar rats ${ }^{42}$.

\section{Hypolipidemic Activity:}

Since ancient time, varieties of herbal medicine have been used in the treatment of various cardiovascular diseases. Sulieman et al correlated the lipid lowering effect of seeds of $C$. dichotoma for the treatment of cardiovascular diseases. In the hyperlipidemic study, male albino rats were fed high-fat diet (HFD) for 10 weeks. Hyperlipidemic rats were divided into three groups; rats fed HFD only as HFD-control group, rats fed HFD and supplemented with $C$. dichotoma pulp (CDP) in two levels 10\% (HFD-CDP10\% group) and $20 \%$ (HFD-CDP20\% group). In normal rats; NDCDP20\% caused significantly decreased of risk ratio about $57.9 \%$ with respect of ND-control. Liver and kidney functions of hyperlipidemic rats were improved with two levels supplemented of CDP. The results of pathological indicated that Increasing of CDP to $20 \%$ cause decrease in fatty changes in the liver of rats. The results of the study suggested that CDP has a strong hypolipidemic action and for the need for further studies in order to evaluate the impact of nutritional components of different extracts, identification of active constituents and investigate the hypolipidemic mechanism of $C$. dichotoma fruits ${ }^{43}$.

Anticancer activity:

Phenolics and carotenoids are mainly present in leaves of $C$. dichotoma which have potent antioxidant activity and can show anticancer activity too. ${ }^{8,14,44}$

Rahman et al have evaluated anticancer activity (apoptosis inducing effect) of methanolic extract of $C$. dichotoma leaves on human cervical cancer cell line, HeLa and to determine total phenolic content. MTT assay and DAPI staining test were performed to evaluate anticancer potential and to assess apoptosis induced effect of methanolic extract of $C$. dichotoma leaves (MECD) against human cervical cancer cell line (HeLa). Results showed that MECD with obtained IC50 of 202 $\mu \mathrm{g} / \mathrm{mL}$ inhibited in vitro proliferation of human cervical cancer cells and apoptosis inducing action indicating its promising anticancer activity as compared to the standard tamoxifen with obtained IC50 of $48 \mu \mathrm{g} / \mathrm{mL}$. Total phenolic contents were found to be $176.5 \mathrm{mg}$ GAE/g dried extract. Thus, methanolic extract of $C$. dichotoma leaves could be a novel potent chemotherapeutic agent for human cancer because of its promising activity and may be considered for further clinical studies in drug development ${ }^{45}$.

\section{CONCLUSION AND FUTURE PROSPECTIVE}

Over the past two decades, much scientific information has been accumulated regarding phytochemicals and pharmacology of $C$. dichotoma. However, this information has not been collectively discussed together, which is very important in understanding the therapeutic utility of this plant.

Various compounds like flavonoids, triterpenes, tannins, alkaloids and fatty acids possessing different bioactivities were isolated from different parts of this plant. The various pharmacological studies carried out with extracts of different parts indicates that the $C$. dichotoma possess analgesic, anti-inflammatory, antimicrobial, antiviral, wound healing, antidiabetic and antifertility activities. Due to the very long tradition using $C$. dichotoma for management of various diseases and also because of what is known today about its chemical constituents and biological activities, it seems to be worth the effort of exploring this plant further and such information may be used for further research work related to C. dichotoma and other traditional systems of medicine.

Financial support and sponsorship: Nil

Conflict of Interest: There are no conflicts of interest 


\section{REFERENCES}

1. Ganjare AB, Nirmal SA, Patil AN. Use of apigenin from Cordia dichotoma in the treatment of colitis. Fitoterapia 2011; 82:10521056.

2. Bhattacharya P, Saha A. Evaluation of reversible contraceptive potential of Cordia dichotoma leaves extract. Rev. Bras. Farmacogn. 2013; 23(2):342-350.

3. Jamkhande PG, Barde SR, Patwekar SL, Tidke PS. Plant profile, phytochemistry and pharmacology of Cordia dichotoma (Indian cherry): A review, Asian Pac J Trop Biomed 2013; 3(12):1009. 1012 .

4. Hussain N, Kakoti BB. Review on ethno botany and psychopharmacology of Cordia dichotoma. Journal of Drug Delivery and Therapeutics 2013;3(1):110-113.

5. Mahasweta R, Kumar B, Kumar N, Patel A, Kumar B. Antioxidant activity of taxifolin obtained from methanolic extracts of $C$ dichotoma Linn. seeds. Int J Pharm Sci Res 2014; 5(7):2896-2901.

6. Singh R, Lawania RD, Mishra A, Gupta R. Role of Cordia dichotoma seeds and leaves extract in degenerative disorders. Int. J Pharm Sci Rev Res 2010; 2(1):21-24

7. Awad AB, Chinnman M, Fink CS, Bradford PG. Beta-sitosterol activates Fas signaling in human breast cancer cells. Phytomed 2007; 14:747-754.

8. Consolacion YR, Virgilio EJ, Mariquit MDLR, Emelina HM, Maria CST, Robert B, et al. Chemical Constituents of Cordia dichotoma G. Forst., Journal of Applied Pharmaceutical Science 2015; 5 Suppl 2:016-021

9. Pankaj B. Nariya, Nayan R. Bhalodia, Vinay J. Shukla, Rabinarayan Acharya, Mukesh B. Nariya, In vitro evaluation of antioxidant activity of Cordia dichotoma (Forst f.) bark, AYU 2013; 34(1):124128

10. Nariya PB, Bhalodia NR, Shukla VJ, Acharya RN. Antimicrobial and antifungal activities of Cordia dichotoma (Forester F.) bark extracts. AYU 2011; 32:585-589.

11. Thirupathi K, Kumar SS, Raju VS, Ravikumar B, Krishna DR, Mohan GK. A review of medicinal plants of the genus Cordia: their chemistry and pharmacological uses. J Nat Rem 2008; 8(1):1-10.

12. Sharma A, Bhardwaj S, Mann AS, Jain A, Kharya MD. Screening Methods of Antoxidant Activity: An Overview, Phcog Rev 2007; 2:232-238

13. Venkateswarlu S, Ramachandra MS, Krishnaraju AV, Trimurtulu G, Subbaraju GV. Antioxidant and antimicrobial activity evaluation of polyhydroxycinnamic acid ester derivatives. Indian J Chem 2006 45B:252-257.

14. Nguyen AT, Malonne H, Duez P, Vanhaelen-Fastre R, Vanhaelen M, Fontaine J. Cytotoxic constituents from Plumbago zeylanica. Fitoterapia 2004; 75:500-504.

15. Al-Musayeib N, Shagufta P, Fatima I, Nasir M, Hussain A Antioxidant, Anti-Glycation and Anti-Inflammatory Activities of Phenolic Constituents from Cordia sinensis. Molecules 2011; 16:10214-10226

16. Gaurav S, Navneet N, Sandeep R, Singh P, Porwal A, Nagpal MA, et al. Effect of aqueous leaves extract of Cordia dichotoma on blood glucose levels of normoglycemic \& alloxan induced diabetic wister rats. Int J Pharm Res Dev 2010; 2:13-14.

17. Basu NG, Ghosal PK, Thakur S. Structural studies on a polysaccharide fraction from the fruits of Cordia dichofoma Forst Carbohydr Res 1984;131:149-155

18. Scheeren L.W, Schneider PSP, Schneider PR, Finger CAG Crescimentodo louro-pardo, Cordia trichotoma (Vell.) Arrab. ex Steud., na Depressão Centraldo estado do Rio Grande do Sul. Ciência Florestal 2002; 12:169-176.

19. Panghal M, Kaushal V, Yadav JP. In vitro antimicrobial activity of tenmedicinal plants against clinical isolates of oral cancer cases. Ann. Clin. Micro-biol. Antimicrob 2011a:10:21.

20. Kumari RM, Thapa N, Gupta N, Kumar A, Nimesh S. Antibacterial and photocatalytic degradation efficacy of silver nanoparticles biosynthesized using Cordia dichotoma leaf extract, Adv. Nat. Sci.: Nanosci. Nanotechnol. 2016;7:045009(8pp)

21. Khan S, Patel A, Bhise K. Antioxidant activity of pomegranate pee powder. Journal of Drug Delivery and Therapeutics, 20172017; 7(2):81-84. doi:10.22270/jddt.v7i2.1380

22. Ghosh R, Deb P. A study on antioxidant properties of different bioactive compounds, Journal of Drug Delivery and Therapeutics 2014;4(2):105-115

23. Killedar S, More H, Mali S, Nadaf S, Salunkhe S, Karade R. Phytochemical screening and in vitro antioxidant potential of memecylon umbellatum burm leaf extracts, Journal of Drug Delivery \& Therapeutics 2014; 4(2):30-35

24. Kaur C, Kapoor HC. Anti-oxidant activity and total phenolics content of some Asian vegetables, Int J Food Sci Technol 2002; 37:153-61.

25. Shuge T, Feng L, Zhang X, Upur H. Phytochemical composition and antioxidant capacity of Cordia dichotoma seeds, Pak. J. Pharm. Sci 2014; 27(5):1123-1129

26. Wang Y, Kazuhiro O, Ryoji K, Kazuo Y. Nat. Medicines 1996; 50(5):367.

27. Wassel G, El-Menshaw B, Saud A, Meharuna G. and El-Merzabani M. Screening of selected plant for Pyrrolizidine alkaloids and antitumor activity, Pharmazine 1987; 42:709.

28. Boparai A, Niazi J, Bajwa N, Singh PA, A review update on Dillenia Indica F. Elongata (MIQ.) MIQ. Journal of Drug Delivery and Therapeutics. 2016; 6(2):62-70 doi:10.22270/jddt.v6i2.1226

29. Thirupathi K, Kumar SS, Goverdhan P, Ravikumar B, Krishna D, Mohan GK, Hepatoprotective Action of Cordia dichotoma Against Carbon Tetrachloride Induced Liver Injury In Rats, Nigerian J Nat. Products and Medicine 2007;11:37-40.

30. Dakappa S, Adhikari R, Timilsina S, Sajjekhan S. A review on the medicinal plant psidium guajava linn. (Myrtaceae). Journal of Drug Delivery and Therapeutics, 2013; 3(2):162-168. doi: $10.22270 /$ jddt.v3i2.404

31. Shibeshi W, Makonnen E, Zerihun L, Debella A. Effect of achyranthes aspera L. on fetal abortion, uterine and pituitary weights, serum lipids and hormones, African Health Sciences 2006;6(2):108-112

32. Sharma P, Manjusha, Rani S, Malhotra H, Nitesh, Deswal S, et al. Antifertility potential of hydroalcoholic extract of Cordia dichotoma G Forst. Leaves: A folklore medicine used by Meena community in Rajasthan state in India, Asian Pacific Journal of Reproduction 2015; 4(2):100-105.

33. Katolkar PP, Wanjari BE, Nimbekar TP, Duragkar NJ. Antiimplantation activity of the methanolic extract of Cordia dichotoma Lam. barks in rats. Int J Biomed \& Adv Res 2012; 3:202-204.

34. Shahapurkar AA, Jayanthi. Drug neomycin release from Cordia dichotoma transdermal film and anti-inflammatory activity. Int Res J Pharm 2011; 2(9):107-109.

35. Sharma VK, Asati DP. Pediatric contact dermatitis. Indian J Dermatol.Venereol. Leprol 2010; 76:514-520.

36. Gupta R, Kaur J. Evaluation of analgesic, antipyretic and antiinflammatory activity on Cordia dichotoma G. Forst. Leaf, Pharmacognosy Res 2015; 7(1):126-130.

37. Kuppasta IJ, Nayak PV. Wound healing activity of Cordia dichotoma Forst. Fruits. Natural Products Radiance 2006; 5(2):99102.

38. Niranjan P, Kaushal C, Jain, S. Pharmacological investigation of leaves of polypodium decumanum for antidiabetic activity. Journal of Drug Delivery and Therapeutics, 2017; 7(4):69-72. doi:10.22270/jddt.v7i4.1468

39. Holman RR, Turner RC. Oral agents and insulin in the treatment of NIDDM. In: Pickup J, Williams G, editors. Textbook of Diabetes. Oxford: Blackwell; 1991. p. 467-469.

40. Niranjan P, Kaushal C, Jain S. Pharmacological investigation of leaves of polypodium decumanum for antidiabetic activity. Journal of Drug Delivery and Therapeutics, 2017; 7(4):69-72. doi:10.22270/jddt.v7i4.1468

41. Swarnkar R, Kaushal C, Jain S, Hypoglycaemic activity of centratherum anthelminticu in experimental animals. Journal of Drug Delivery and Therapeutics, 2017; 7(4):73-77. doi:10.22270/jddt.v7i4.1472

42. Day C. Traditional plants treatments for diabetes mellitus: Pharmaceutical Foods., Brit. J. Nutr. 1998; 80:5-6.

43. Sulieman AM, El-Newary SA. Hypolipidemic Effect of Cordia dichotoma Forst. Pulp in High-fat Diet-Fed Rats, World Journal of Dairy \& Food Sciences 2014; 9(2):260-271.

44. Owen RW, Giacosa A, Hull WE, Haubner R, Spiegelhalder B, Bartsch H. The antioxidant/ anticancer potential of phenolic compounds isolated from olive oil. Eur J Cancer 2000; 36:1235-47

45. Rahman MA, Hussain A. Anticancer activity and apoptosis inducing effect of methanolic extract of Cordia dichotoma against human cancer cell line, Bangladesh J Pharmacol 2015; 10:27-34 